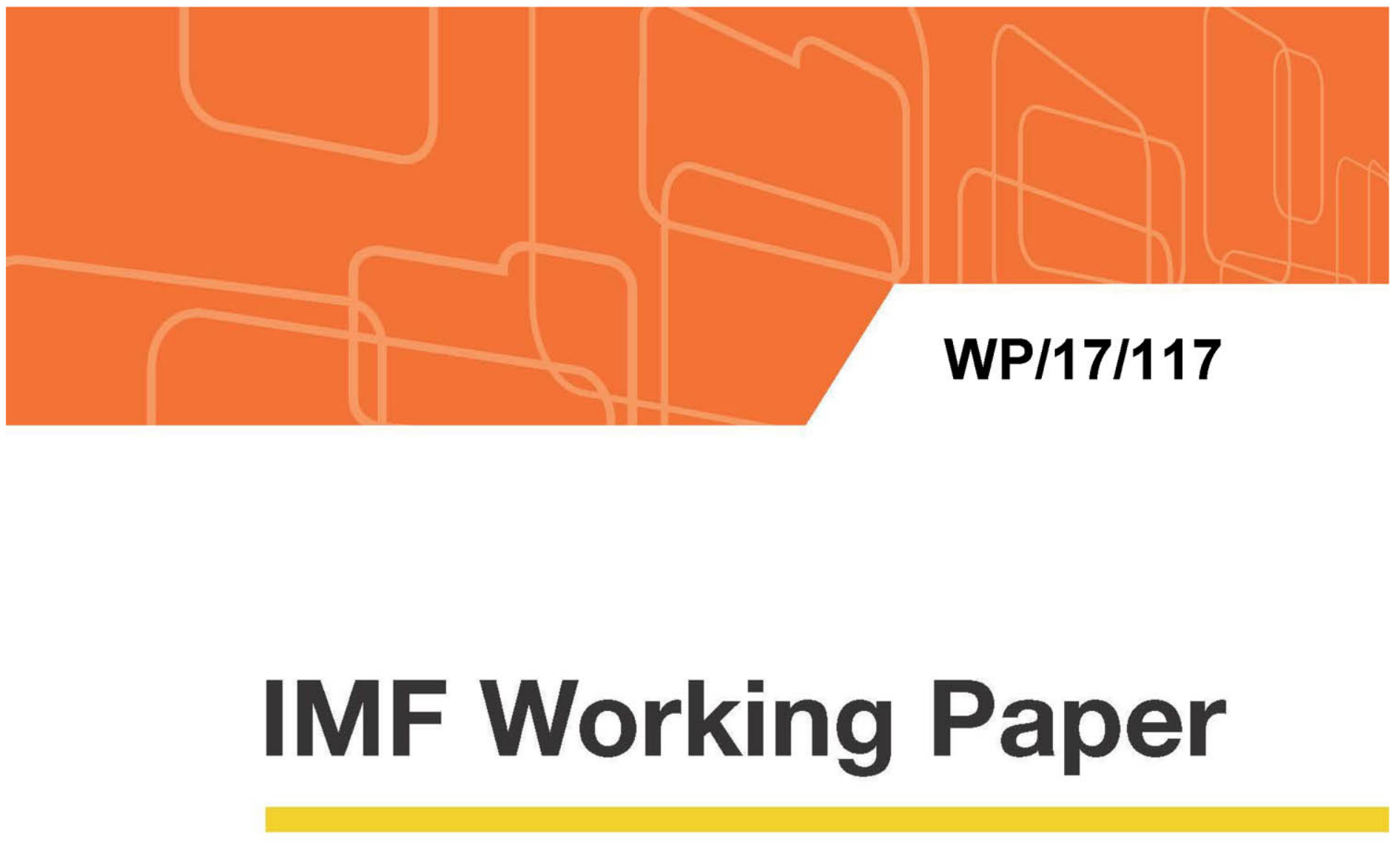

\title{
Debt Limits and the Structure of Public Debt
}

by Alex Pienkowski

IMF Working Papers describe research in progress by the author(s) and are published to elicit comments and to encourage debate. The views expressed in IMF Working Papers are those of the author(s) and do not necessarily represent the views of the IMF, its Executive Board, or IMF management. 


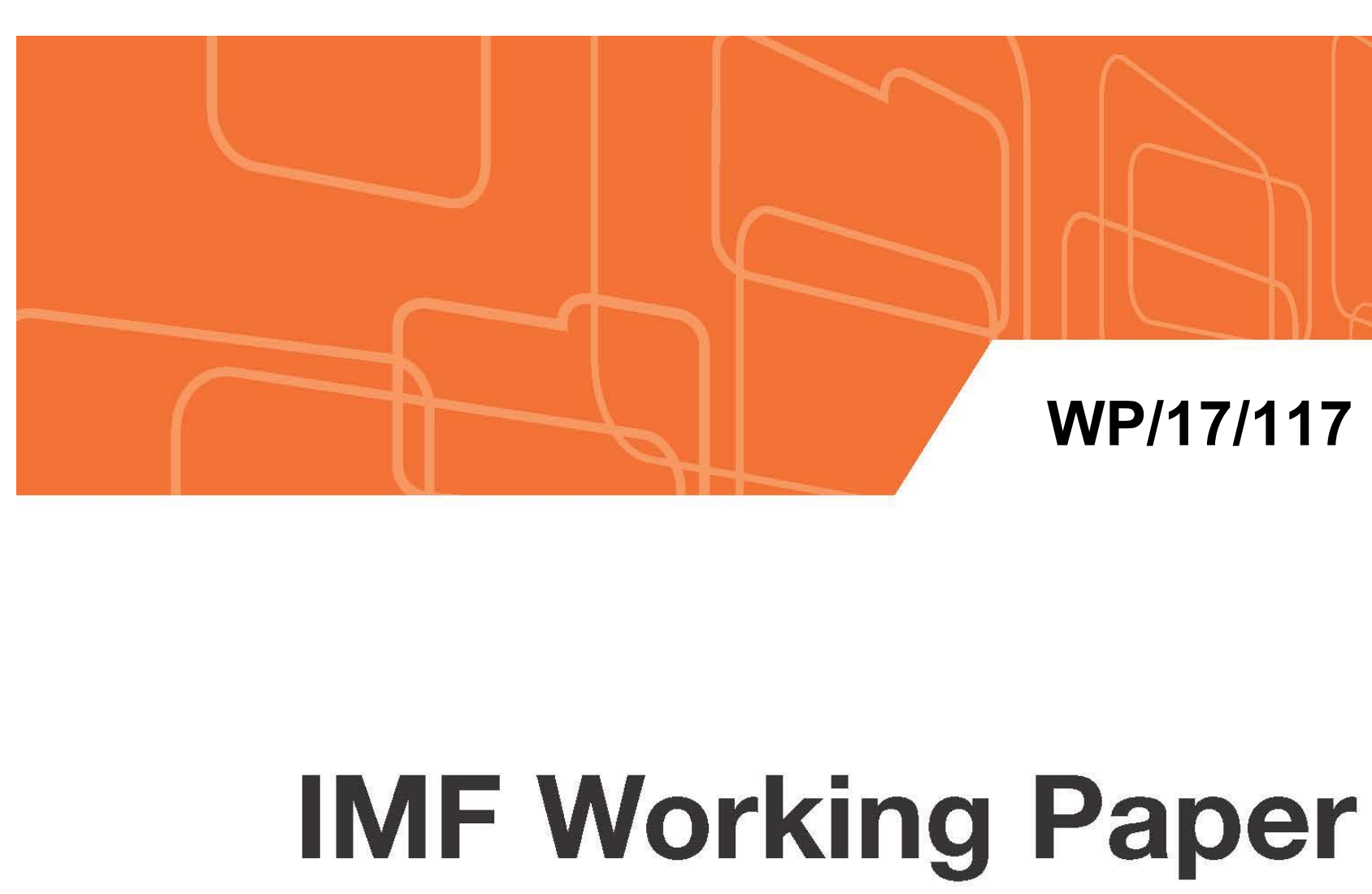

\section{Debt Limits and the Structure of Public Debt}

by Alex Pienkowski

IMF Working Papers describe research in progress by the author(s) and are published to elicit comments and to encourage debate. The views expressed in IMF Working Papers are those of the author(s) and do not necessarily represent the views of the IMF, its Executive Board, or IMF management. 


\title{
IMF Working Paper
}

Strategy, Policy and Review Department

\section{Debt Limits and the Structure of Public Debt ${ }^{1}$ \\ Prepared by Alex Pienkowski}

Authorized for distribution by Mark Flanagan

May 2017

\section{IMF Working Papers describe research in progress by the author(s) and are published to elicit comments and to encourage debate. The views expressed in IMF Working Papers are those of the author(s) and do not necessarily represent the views of the IMF, its Executive Board, or IMF management.}

\begin{abstract}
This paper provides a tractable framework to assess how the structure of debt instruments - specifically by currency denomination and indexation to GDP — can raise the debt limit of a sovereign. By calibrating the model to different country fundamentals, it is clear that there is no one-size-fits-all approach to optimal instrument design. For instance, low income countries may find benefit in issuing local currency debt; while in advanced economies debt tolerance can be substantially enhanced through issuing GDPlinked bonds. By looking at the marginal impact of these instruments, the paper also provides insight into the optimal portfolio compostion.
\end{abstract}

JEL Classification Numbers: H63, F34

Keywords: Sovereign debt, debt limits, sovereign default, state-contingent debt, GDP-linked bonds.

Author's E-Mail Address: apienkowski@imf.org

\footnotetext{
${ }^{1}$ With special thanks to S. Ali Abbas for his guidance and comments on this paper. Thanks also to Sam LaRussa for his research assistance support.
} 


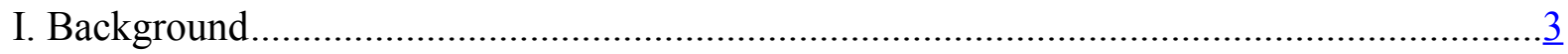

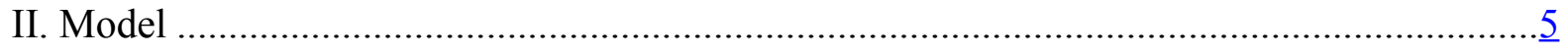

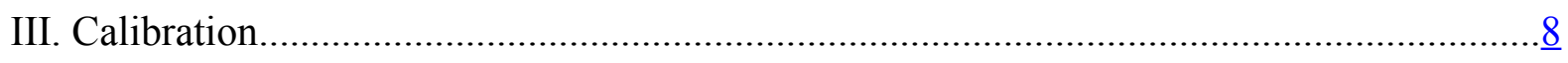

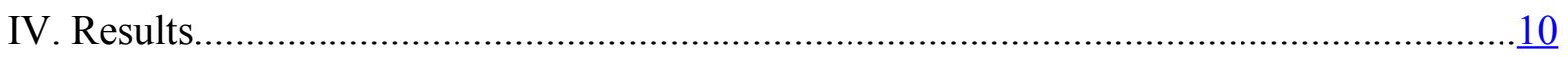

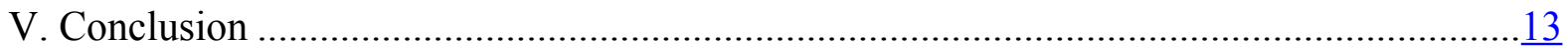

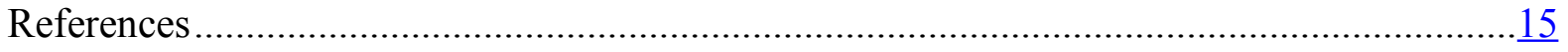

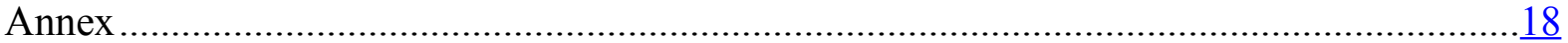




\section{BACKGROUND}

1. In an era of high debt, low and uncertain growth and compressed global interest rates, the potential benefits of issuing instruments that better buffer against macroeconomic shocks are higher than ever. Average public debt in advanced economies has grown from a precrisis level of around 70 percent of GDP, to nearly 110 percent in 2016. At such levels, relatively small macroeconomic shocks, such as a typical recession, can cause debt vulnerabilities to increase substantially. Therefore, insuring against GDP and exchange rate volatility has the potential to substantially reduce risks to debt sustainability. Of course, insurance is rarely free. In today's low interest rate environment, however, sovereign issuers have greater capacity to afford to pay for such protection. And with investors 'searching for yield', they may be more willing to share macroeconomic risks with sovereigns; especially if this also implies a lower risk of default.

2. This paper explores how the structure of sovereign debt can alter the payment capacity of a government. Three broad types of debt instrument are modelled —-foreign currency denominated debt; local currency denominated debt; and debt linked to GDP. Each offer varying degrees of protection to the sovereign's balance sheet from potentially destabilizing shocks. For example, relative to foreign currency debt, local currency debt shields a sovereign's balance sheet from the direct effects of potentially volatile nominal exchange rate movements. Correspondingly, 'GDP-linked bonds' adjust in value in the face of shocks to output, helping to stabilize the debt-to-GDP ratio.

3. These instruments are incorporated into a model of sovereign default to assess the impact they have on a government's debt limit. If debt goes above this limit, then the sovereign will default on its payment obligations; so the higher this threshold, the lower the probability of default. The model incorporates an endogenous credit risk premium to compensate creditors from holding risky debt. And also a premium on issuing local currency and GDP-linked debt to compensate the creditor for bearing this additional risk. In this sense, there is no 'free lunch' for the sovereign, as it must pay for the insurance that it receives from these instruments.

4. It has long been understood that the structure, not just the level, of sovereign debt is an important determinant of sustainability. The role of foreign currency debt and sovereign debt crises is embedded in the broader set of 'balance sheet' models of currency crises (Krugman, 1999, Aghion and others, 1999 and Jeanne and Zettelmeyer, 2002). These models stress the amplification effects of exchange rate depreciations, which raise the debt service burden of (public and private) debt, causing payments problems and hence further pressure on the exchange rate.

5. Similarly, the literature on the maturity structure of sovereign debt-motivated initially by the 1994 Mexico crisis - illustrated how self-fulfilling crises could occur based purely on shifts in market perceptions (Sachs, 1984 and Cole and Kehoe, 2000). Several papers including Allen and others (2002), IMF (2000), IMF and World Bank (2001), Borensztein and others (2004) and Abbas and others (2014) took a more holistic view on the structure of sovereign debt 
crisis prevention. These papers illustrated the value of maturity and currency composition statistics as early warning indicators of crises.

6. In terms of indexing debt to state-variables, Krugman (1988) and Froot and others (1989) proposed explicitly linking debt to commodity prices, exports and real GDP. This initial wave of interest was triggered by the Latin American debt crisis, which illustrated the economic damage caused by prolonged debt overhang problems and risks associated with continued forbearance as a policy strategy. Shiller $(1993,2003)$ was the first to extensively advocate the use of GDPlinked bonds, including a perpetual version, the 'Trill'. The focus of this work was not the reduction of risk to the sovereign balance sheet, but the opportunity that these instruments would give to investors to obtain an 'equity stake' in economic growth i.e., the role these instruments could play in risk diversification. Barro (1995) recognized the benefit of GDP-linked bonds in terms of sovereign debt management; in particular, the role that these instruments could play in welfare enhancing tax-smoothing.

7. Borensztein and Mauro (2004) expanded on the benefits of GDP-linked bonds to both the sovereign and potential investors, arguing that they can reduce the probability of default; limit the need for pro-cyclical fiscal policies; smooth taxes through the cycle; and provide a natural break on pro-cyclical government spending in 'boom times'. Chamon and Mauro (2005) were the first to explicitly model how GDP-linked bonds could reduce the default risk through Monte Carlo simulations. More recently, Blanchard and others (2016) argue the case for GDP-linked bonds in advanced economies, which are currently experiencing historically high debt levels combined with low and uncertain growth. And Benford and others (2016) and Brooke and others (2013) make a broader case for GDP-linked bonds against a backdrop of high debt, low interest rates and, weak and uncertain nominal growth prospects.

8. The foundations of this model are based on the paper by Ghosh and others (2011); and the extension by Barr and others (2014). These models develop the idea that sovereigns seek to stabilize debt through a fiscal reaction function (see Bohn, 1998 and 2005; Abiad and Ostry, 2005; and Mendoza and Ostry, 2007): as the debt level rises, so will the primary balance, until some maximum level is reached. If the maximum primary balance is insufficient to stabilize debt dynamics, then default occurs.

9. This paper builds on the existing literature in a number of ways:

i. In addition to growth and primary balance shocks (as in Barr and others, 2014) it also includes shocks to the exchange rate. This allows an exploration of the role of the currency composition of debt on a sovereign's debt limit, in addition to GDP-linked bonds;

ii. The model is calibrated for a representative country from one of four groups - all countries, advanced economies, emerging markets and low-income countries-each with differing fundamentals. The paper illustrates that there is not one-size-fits-all debt strategy to raise debt levels. 
iii. Finally, the set-up allows the marginal impact of GDP-linked bond issuance on the debt limit to be explored. This shows that substantial benefits from such instruments can be realized even when they represent a relatively small share of the debt stock.

10. In summary, this paper provides a tractable and granular framework for policymakers, academics and market participants to explore the relative benefits of state-contingent debt for specific countries. Nevertheless, an acknowledged limitation of this paper is its inability to model the impact of the maturity structure of debt. The set-up is based upon one-period bonds, which cannot incorporate longer-term instruments. Several recent papers, notably Kim and Ostry (2017), Kim (2015), Lorenzoni and Werning (2013) and Hatchondo and Martinez (2002) have attempted to incorporate the maturity component in models of sovereign default. The obvious extension of this paper would be to incorporate this additional dimension into the analysis.

\section{MODEL}

11. This paper presents a structural model of sovereign default, calibrated on data from country groups with differing fundamentals. The model is based around a primary balance reaction function combined with the automatic drivers of debt - the effective interest rate minus GDP growth - to derive a debt limit. If a sovereign's debt breaches this debt limit, default occurs. The model incorporates shocks to growth, exchange rates and the primary balance.

12. Sovereign debt follows the standard debt accumulation equation:

$$
\Delta d_{t}=\frac{\left(r_{t}-g_{t}\right)}{1+g_{t}} \cdot d_{t}-p b_{t}
$$

where $d_{t}$ is the debt level as a proportion of GDP; $r_{t}$ is the real interest rate on debt; $g_{t}$ is the real GDP growth rate; $p b_{t}$ is the primary balance as a proportion of GDP. All debt has a maturity of one-year. Around this debt dynamics equation, each of the drivers of debt - the interest rate, the primary balance, and growth - are determined by separate behavioral equations. Exchange rate shocks to foreign currency denominated debt are also introduced. Each component is explored in turn.

13. The sovereign reacts to the debt level by adjusting the primary balance to help ensure solvency. As the debt level rises, the primary balance will increase as the sovereign seeks to stabilize debt. However, there is a maximum limit to the level of the primary balance, which can be motivated by public intolerance to fiscal austerity (Mendoza and Ostry, 2007). This fiscal reaction function is constructed as follows:

$$
p b_{t}=\min \left(\alpha+\beta \cdot d_{t}, \gamma\right)+\varepsilon_{t}^{p b}
$$

where the primary balance is the minimum of two values, either i) a positive relationship between the primary balance and the debt level, with an intercept of $\alpha$ and a slope coefficient, $\beta$, or: ii) a maximum primary balance, $\gamma$. This function is also subject to shocks, $\varepsilon_{t}^{p b}$, which can cause the primary balance to temporarily exceed its maximum. 
14. As with Ghosh and others (2011), the return on a sovereign bond $\left(r_{t}\right)$ is determined as follows:

$$
\left(1+r_{t}\right)=\left(1+r^{*}\right) \cdot \frac{\left(1-p_{t+1} \cdot \theta\right)}{\left(1-p_{t+1}\right)}
$$

where $p_{t+l}$ is the probability of default in the next period, $r^{*}$ is the risk-free interest rate and $\theta$ is the recovery value on a bond in the event of default.

15. Finally, the economy is subject to shocks to growth and the nominal exchange rate. Growth is expected to follow a steady-state trend, $g^{*}$, but subject to an exogenous shock, $\varepsilon_{t}^{g}$. The expected value of the change in the exchange rate is zero, but there are exogenous shocks, $\varepsilon_{t}^{e r}$. The impact on debt of this shock will depend on the share of foreign currency denominated debt, $F_{t}$. Combining equations 2 and 3 , and the shocks to growth and exchange rates, into equation 1 generates the following debt dynamics equation:

$\Delta d_{t}=\left(\left(1+r^{*}\right) \cdot \frac{\left(1-p_{t+1} \cdot \theta\right)}{\left(1-p_{t+1}\right)}-1-g^{*}+\varepsilon_{t}^{g}\right) \cdot \frac{d_{t}}{\left(1+g^{*}+\varepsilon_{t}^{g}\right)}+d_{t} \cdot F_{t} \cdot \varepsilon_{t}^{e r}-\left(\min \left(\alpha+\beta \cdot d_{t}, \gamma\right)+\varepsilon_{t}^{p b}\right)$

where: i) the first product captures the automatic debt dynamics, determined by the growthinterest rate differential, including the credit spread (captured by the probability of default and recovery rate), and also shocks to growth; ii) the second product shows the impact from exchange rate shocks, which depends on the share of foreign currency denominated debt; and, iii) the third product shows the primary balance, determined by the fiscal reaction function and exogenous shocks. Whether debt increases or decreases in any one period depends upon the random shocks to growth, the primary balance and exchange rates; and the response from both the government (through the fiscal reaction function) and the markets (through the endogenous credit spread).

16. The credit spread in equation 4 is a function of the investors' perceived probability of default. In order to construct this probability, the concept of a debt limit, $\bar{d}$, is introduced. The limit is defined as the highest level of debt that a sovereign can sustain at finite interest rates while satisfying its fiscal constraint and the interest rate equilibrium condition. The probability of default is the probability that the current debt will breach this debt limit threshold in the next period:

$$
p_{t+1}=\operatorname{pr}\left(d_{t+1}>\bar{d}\right)
$$

17. Considering equations 4 and 5 , it is clear that the both the credit spread and the debt limit are endogenously determined. A lower debt limit increases the likelihood of default and therefore the credit spread demanded by investors. A higher credit spread worsens debt dynamics by reducing the growth-interest rate differential, which in turn lowers the debt limit. The model is solved numerically by finding the highest level of debt that can sustain a probability of default below 1 , and where both $\bar{d}$ and $p_{t+1}$ satisfy the following inequality: 


$$
p_{t+1}=\operatorname{Pr}\left[\left(\left(1+r^{*}\right) \cdot \frac{\left(1-p_{t+1} \cdot \theta\right)}{\left(1-p_{t+1}\right)}-1-g^{*}+\varepsilon_{t}^{g}\right) \cdot \frac{\bar{d}}{\left(1+g^{*}+\varepsilon_{t}^{g}\right)}+\bar{d} \cdot F_{t} \cdot \varepsilon_{t}^{e r}-\left(\min (\alpha+\beta \cdot \bar{d}, \gamma)+\varepsilon_{t}^{p b}\right) \geq 0\right]
$$

18. Once the model parameters are calibrated (see below), simulations are undertaken to find the debt limit for each country group. This constitutes a fixed-point problem, as discussed in Kim and Ostry (2017) and Ghosh and others (2011). The numerical simulations essentially find the highest level of debt where the probability of default is not certain i.e., is below 1 (and greater or equal to zero, as a negative probability of default does not make economic sense).

19. Given that the debt limit and probability of default are endogenously derived, the following exogenous factors determine a sovereign's debt limit. While there is a non-linear relationship between these variables and the debt limit, the direction of the relationship is unambiguous.

\begin{tabular}{|lc|}
\hline \multicolumn{2}{|c|}{ Text Table. Parameter Impact on Debt Limit } \\
\hline Parameter & $g^{*}$ \\
\hline Steady-state real growth & $\theta$ \\
Default recovery rate & $V$ \\
Maximum primary balance & $r^{*}$ \\
Risk free rate & $F_{t}$ \\
Share of foreign currency debt & $\operatorname{std}\left(\varepsilon_{t}^{p b}, \varepsilon_{t}^{g}, \varepsilon_{t}^{e r}\right)$ \\
Standard deviations of shocks & $r^{g d p}, r^{e r}$ \\
Growth and exchange rate premia &
\end{tabular}

20. Once the debt limit of a representative country is estimated, it is possible to consider the impact that different contract designs can have on raising, or in some cases lowering, the debt limit. Two types of instruments are considered - local currency bonds and GDP-linked bonds. Such instruments act to insulate sovereign debt from exchange rate and GDP shocks. But they also come with a price in the form of a premium required by the creditor to assume this increased volatility in their returns. Both effects impact the debt limit in opposite directions.

21. GDP-linked bonds are designed so that the principal payment is indexed to the level of nominal GDP. The coupon payment is a fixed percentage of the indexed principal, so also varies with GDP. This design is similar to U.K. inflation linked bonds and follows the structure set out in the "London Term Sheet" (ICMA, 2017). With these bonds, the impact of the GDP shock on the debt ratio declines as the share of these bonds increase. When all debt is GDP-linked, then GDP shocks will not affect the debt-to-GDP ratio. To clarify this, assume that both the interest rate and primary balance are equal to zero, so that only GDP growth changes the debt-to-GDP ratio. The following identity shows the path of conventional bonds:

$$
\frac{D_{t+1}}{G D P_{t+1}}=\frac{D_{t+1}}{G D P_{t} \cdot\left(1+g_{t+1}\right)}
$$


Here the debt-to-GDP ratio will follow a random walk, which will depend on the past history of growth shocks. Next, assume that the debt level is linked to the level of GDP (using the same contract design as U.K. CPI-linked bonds). A shock to GDP will impact both the numerator (debt) and the denominator (GDP) by the same amount. Therefore, the debt-to-GDP ratio remains constant regardless of the size of growth shocks i.e., the GDP-shocks are eliminated:

$$
\frac{D_{t+1}^{g d p}}{G D P_{t+1}}=\frac{D_{t}^{g d p} \cdot\left(1+g_{t+1}\right)}{G D P_{t} \cdot\left(1+g_{t+1}\right)}=\frac{D_{t}^{g d p}}{G D P_{t}}
$$

22. The protection provided by local currency debt is easily modelled. The share of foreign currency debt, $\mathrm{F}_{\mathrm{t}}$, simply adjusts in equations 4 and 6 , thus changing the share of debt which is affected by shocks to the exchange rate. The premiums that creditors demand in order to bear the sovereign's exchange rate and GDP volatility ( $r^{e r}$ and $r^{g d p}$, respectively) are invariant through time, and are unrelated to the debt level. These are simply added to the risk free rate $\left(r^{*}\right)$ in equations 4 and 6 .

\section{Calibration}

23. The model is calibrated using historical data for a representative country from four groups (Table 1): All Countries (ACs), Advanced Economies (AEs), Emerging Markets (EMs) and Low-Income Countries (LICs). These various country groups have different macroeconomic fundamentals, and these are constructed as follows:

a. Maximum primary balance $(\gamma)$ - The $90^{\text {th }}$ percentile of cyclically adjusted primary balances from the sample of fiscal consolidation episodes outlined in Escolano, Jaramillo, Mulas-Granados and Terrier (2014).

b. Shocks to real GDP growth $\left(\varepsilon_{t}^{g}\right)$, the primary balance $\left(\varepsilon_{t}^{p b}\right)$ and the nominal exchange rate $\left(\varepsilon_{t}^{e r}\right)$-Data taken from the IMF WEO, and then demeaned. The shocks are applied to the model using 'bootstrap' simulations, with the same shocks to the three variables coming from the same country and year (histograms displayed in Figures A1-A12). This means that the contemporaneous correlations (Table A1) between the variables are maintained in the model. ${ }^{2}$

c. Steady-state growth rate $\left(g^{*}\right)$ - The WEO database includes long-run growth (1960-2015) values for key country groupings. This corrects for countries moving between country classifications through time.

\footnotetext{
${ }^{2}$ A potential extension to this paper could 'endogenize' these correlations to the debt structure, for instance to capture potential balance sheet effects from exchange rate shocks
} 
d. Share of foreign currency debt $\left(F_{t}\right)$ - The average share by country group taken from the WEO database.

e. Default recovery rate $(\theta)$ - An 80 percent recovery rate is assumed if a default occurs. This is calibrated using the average face value haircut on restructurings from the Cruces and Trebesch (2013) database. ${ }^{3}$

Table 1. Country Groups

\begin{tabular}{llcc}
\hline \multicolumn{1}{c}{ Country Group } & \multicolumn{1}{c}{ Definition } & $\begin{array}{c}\text { Number of } \\
\text { countries }\end{array}$ & $\begin{array}{c}\text { Number of } \\
\text { observations }\end{array}$ \\
\hline All countries & All countries in the WEO database & 194 & 3,965 \\
Advanced economies & As defined in the WEO database & 37 & 962 \\
Emerging markets & All countries not designated as AEs or LICs & 79 & 1,566 \\
Low income countries & PRGT-eligible countries as of 2015 & 73 & 1,415 \\
\hline
\end{tabular}

Note: Time span of annual data varies by country, with an average of 20 years

24. Table 2 summarizes the parameters used in this model, derived from the data explained above. The main stylized facts are as follows. EMs and LICs have a higher steady-state growth rate than AEs, but are subject to larger growth shocks around this trend. The maximum primary balance of the country groups is positively associated with average per capita incomes: AEs have the highest maximum primary balance ( 7 percent of GDP), while LICs have the lowest (4 percent of GDP). In addition, poorer countries tend to have more volatile primary balance shocks than AEs. Exchange rate shocks are similar across groups. But the share of foreign currency denominated debt also appears broadly inversely proportional to country's income level.

Table 2. Model Calibration

\begin{tabular}{|c|c|c|c|c|c|c|c|c|}
\hline Country Group & $\begin{array}{c}\text { Steady } \\
\text { state real } \\
\text { growth }\end{array}$ & $\begin{array}{c}\text { Maximum } \\
\text { primary } \\
\text { balance }\end{array}$ & $\begin{array}{c}\text { Share of } \\
\text { foreign } \\
\text { currency } \\
\text { debt }\end{array}$ & $\begin{array}{l}\text { StDev - real } \\
\text { growth shock }\end{array}$ & $\begin{array}{c}\text { StDev - } \\
\text { primary } \\
\text { balance } \\
\text { shock }\end{array}$ & $\begin{array}{c}\text { StDev - } \\
\text { exchange } \\
\text { rate shock }\end{array}$ & $\begin{array}{c}\text { Exchange } \\
\text { rate } \\
\text { volatility } \\
\text { risk } \\
\text { premium } \\
\end{array}$ & $\begin{array}{c}\text { Real GDP } \\
\text { volatility risk } \\
\text { premium }\end{array}$ \\
\hline & $\begin{array}{l}\text { percentage } \\
\text { points }\end{array}$ & $\begin{array}{c}\text { percent of } \\
\text { GDP }\end{array}$ & $\begin{array}{c}\text { percent of } \\
\text { total debt }\end{array}$ & $\begin{array}{l}\text { percentage } \\
\text { points }\end{array}$ & $\begin{array}{c}\text { percentage } \\
\text { points of } \\
\text { GDP }\end{array}$ & $\begin{array}{l}\text { percentage } \\
\text { points }\end{array}$ & $\begin{array}{l}\text { percentage } \\
\text { points }\end{array}$ & $\begin{array}{l}\text { percentage } \\
\text { points }\end{array}$ \\
\hline All countries & 3.3 & 6.0 & 55 & 4.1 & 3.8 & 10.3 & 2.3 & 2.0 \\
\hline Advanced economies & 2.9 & 7.0 & 0 & 3.0 & 2.3 & $\mathrm{n} / \mathrm{a}^{1}$ & $\mathrm{n} / \mathrm{a}^{1}$ & 1.5 \\
\hline Emerging markets & 5.0 & 5.5 & 50 & 4.4 & 3.9 & 9.9 & 1.9 & 2.1 \\
\hline Low income countries & 5.0 & 4.0 & 70 & 4.2 & 4.6 & 10.2 & 2.3 & 2.0 \\
\hline
\end{tabular}

${ }^{1} \mathrm{AEs}$ are assumed to have no foreign currency denominated debt, so this shock does not apply

25. The GDP and exchange rate volatility premiums are calculated using a 'certaintyequivalent' framework. This method compensates investors for the variance in returns - the

\footnotetext{
${ }^{3}$ The 'preferred haircut' methodology in this paper estimates a median haircut around 30 percent (70 percent recovery rate). However, this uses a present value concept, which is inconsistent with the one-period debt set-up in this model. While lowering the recovery rate in the model reduces the 'baseline' debt limit for all countries, the relative impact from different debt structures remains similar.
} 
greater the uncertainty of returns, the higher the compensation needed by the investor. ${ }^{4}$ The certainty equivalent methodology is based around the simple assumption that investors are risk averse, and have a utility function with constant relative risk aversion:

$$
U(c)=\frac{1}{1-\delta} c^{1-\delta}
$$

where $\mathrm{c}$ is consumption, measured by the return on the instrument; and $\delta$ measures the degree of relative risk aversion, assumed to be 2 , which is standard in the literature. For each of the growth and exchange rate shocks summarized in Figures A1-12, the investor's utility associated with this outturn is calculated, and compared to the utility associated with a guaranteed return. The risk premium is calculated as the interest rate needed to ensure that the investor is indifferent between the risky and safe bond. These premia are shown in Table 2. As investors prefer certainty in returns, a higher standard deviation of growth and exchange rates implies a higher premium on these instruments.

\section{RESUlts}

26. Table 3 shows the 'baseline' debt limit, derived by this model, for a representative country from each of the four groups. This debt limit - the maximum sustainable debt level before a default occurs - varies by the fundamentals of each country groups, summarized in Table 2. These baseline debt levels make broad intuitive sense. ${ }^{5}$ AEs have the highest debt limit, as they can sustain a relatively high maximum primary surplus, which help to stabilize debt in the face of shocks. In contrast, LICs have both a low maximum primary balance and are subject to much larger shocks, although they do have a higher trend growth rate, which helps raise the debt limit. The fact that LICs and EMs have foreign currency denominated debt also exposes them to destabilizing exchange rate shocks, which lowers the debt limit relative to AEs.

\footnotetext{
${ }^{4} \mathrm{An}$ alternative approach would be to adopt a CAPM framework whereby the investor is compensated for the correlation of returns with the wider market. However, the correlation between real GDP growth in these country groups and indices such as the S\&P500 are very low (see also Bowman and Naylor, 2016 and Kamstra and Shiller, 2009) implying a low risk premium. In order to be conservative, this paper uses the 'certainty equivalent' method instead.

${ }^{5}$ In some cases, these debt limits may appear on the low side. But it is important to bear in mind that: i) these are averages for country groups; ii) the model does not capture concessional borrowing (especially by LICs); and iii) there is no scope in the model for policies such as external emergency liquidity assistance, financial repression or monetary financing. Furthermore, given that LICs have limited access to commercial borrowing, the endogenous interest rate reaction to default risk modelled here will not entirely capture the underlying debt dynamics of this country group. Nevertheless, the relative differences between the country group debt limits meets broad priors.
} 
Table 3. Debt Limits with Various Instrument Designs

\begin{tabular}{lccccc}
\hline Country Group & $\begin{array}{c}\text { Baseline debt } \\
\text { limit }\end{array}$ & $\begin{array}{c}\text { Debt limit - 100\% } \\
\text { local currency }\end{array}$ & $\begin{array}{c}\text { Debt limit - 100\% } \\
\text { local currency; } \\
\text { 20\% GDP linked }\end{array}$ & $\begin{array}{c}\text { Debt limit - 100\% } \\
\text { local currency; } \\
\text { 50\% GDP linked }\end{array}$ & $\begin{array}{c}\text { Debt limit - 100\% } \\
\text { local currency; } \\
\text { 100\% GDP linked }\end{array}$ \\
\hline All countries & & & percent of GDP & & \\
Advanced economies & 52 & 78 & 80 & 84 & 84 \\
Emerging markets & 137 & 137 & 152 & 175 & 238 \\
Low income countries & 58 & 98 & 106 & 120 & 140 \\
\hline
\end{tabular}

27. Now that the baselines are derived, the impact from increasing local currency or GDPlinked bond issuance can be estimated. Moving towards full local currency denominated debt raises the debt limits of all country groups (AEs are assumed to already have full local currency debt). This is shown in the second column of figures in Table 3. The increase is especially pronounced for EMs, where the debt limit increases by 40 percentage points of GDP (a 70 percent increase relative to the baseline). This implies that exchange rate shocks are a significant risk to EM solvency. By eliminating this risk (and after taking into account the higher risk premia on local currency debt), the credit spread demanded by investors declines, and therefore the debt limit of the country increases. LICs also benefit, with the debt limit increasing by 14 percentage points of GDP. However, the absolute and relative impact on the debt limit is less than for EMs. LICs are vulnerable to exchange rate shocks, but the risk of a growth or primary balance shock are also important. Therefore, while the risk of default declines with greater local currency debt issuance, the impact on the debt limit is less (i.e., growth and primary balance shocks remain a major risk).

28. Next, the impact of GDP-linked bonds on the debt limit is considered. It is unlikely that any sovereign would issue all of their debt in GDP-linked bonds. However, even issuing relatively modest amounts - say 20 percent of

Debt limits

(Percent of GDP)

the total debt stock — can have a significant impact on the debt limit. For AEs, the debt limit would rise by around 15 percentage points of GDP, which would be enough to accommodate the median fiscal costs of a systemic banking crisis. ${ }^{6}$ An 8 percentage point increase in the debt limit for EMs is also substantial, enough to accommodate additional borrowing through a typical recession (IMF, 2016). For LICs, however, there is no change in the debt limit (relative to the case where 100 percent of debt is local

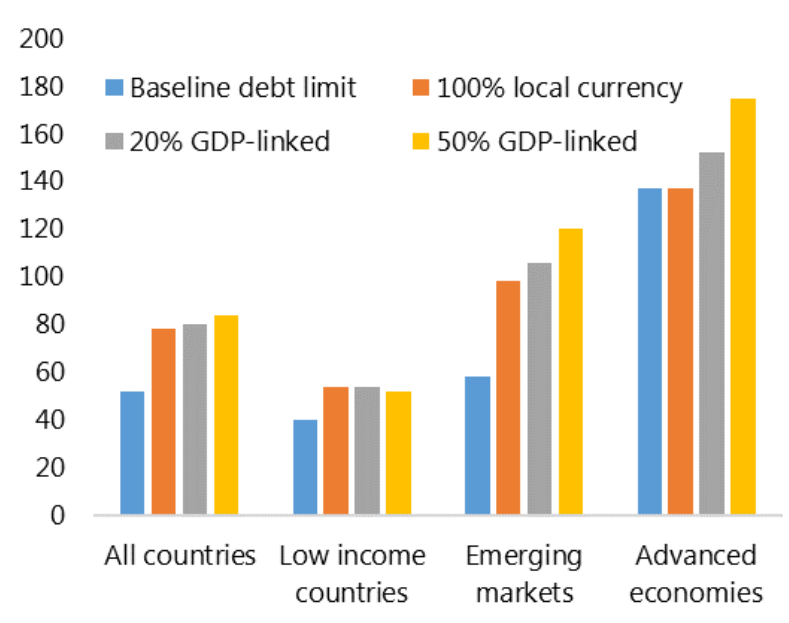

\footnotetext{
${ }^{6}$ Amaglobeli and others (2015) estimate that the direct fiscal cost of a systemic banking crisis (recapitalization and asset purchases) has a median of 6 percent of GDP; while the median increase in public debt associated with these events is around 14 percent of GDP.
} 
currency denominated). Here, the higher interest rate costs associated with paying the GDPvolatility premium offset the benefits from smaller GDP shock on debt. For both AEs and EMs, the debt limit continues to rise as the share of GDP-linked bonds increases. If half of debt is GDP-linked, AEs experience an increase in the debt limit of around 40 percentage points, enough to accommodate all but the worst tail-events. EMs also experience a sizable increase, around 20 percentage points of GDP compared to the scenario where all debt is local currency.

29. The results also show that the marginal impact on the debt limit from raising the share of GDP-linked bonds can be diminishing, or even negative. This is illustrated by the marginal impact of moving to full GDP-linked bond issuance. For LICs, there is actually a Marginal Change in Debt Limit modest decrease in the debt limit i.e., the marginal impact is negative. This is because the GDP-risk premium lowers the debt level by more than the positive effect from lower GDP volatility. Similarly, EMs have a maximum debt limit which occurs when GDP-linked bonds are below 100 percent coverage (Figures A13-A16 show the debt level for each group as the share of GDP linked bonds rise). For AEs, the debt level continues to increase with the share of GDP-linked bonds, and hence reaches a maximum when all debt is GDP-linked.

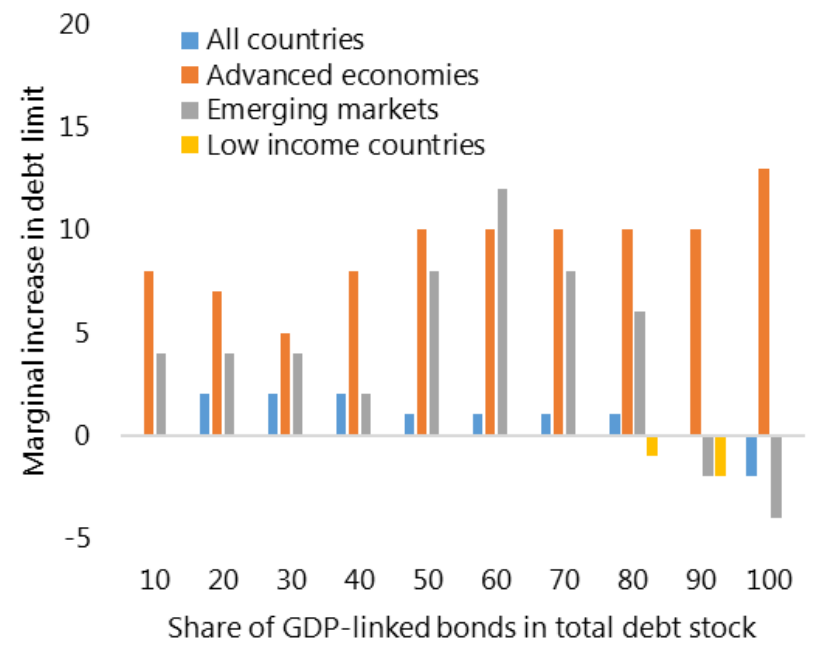

30. This does not, however, imply that the share of GDP-linked bonds that maximizes the debt limit is necessarily 'optimal'. A sovereign may have risk tolerance preferences whereby they opt for a lower debt limit in order to reduce debt service costs. This is also consistent with 'myopic' preferences, whereby policymakers don't fully internalize the costs of debt crises. Furthermore, a high share of GDP-linked bonds could have other unintended consequences such as - i) a reduction in the supply of 'safe' conventional assets, which are important for financial market transactions; ii) excessive risk being transferred to the private sector, which could cause business cycles to become more volatile, and; iii) an increased risk of moral hazard or incentives to manipulate data by the sovereign. However, an assessment of these factors is beyond the scope of this analysis.

31. The size of the GDP and exchange rate premium is an important determinant in the marginal increase (or decrease) in the debt limit. In order to provide some sensitivity analysis, the impact of a plus or minus 2 percentage point change in the premiums is shown in Tables 4 and 5. The size of the differences in debt limits is striking. For example, a 4 percentage point difference in the GDP risk premium for AEs implies a 170 percentage point difference in the debt limit. Clearly the uncertainty over the risk premium for these instruments is an important limiting factor in assessing their potential benefits. However, the 'break even' risk premium may 
be more informative. This shows the risk premium that delivers the same debt limit as under the baseline debt level (for the GDP risk premium, this is relative to the full local currency debt scenario). This means that all levels of risk premium below this break-even level cause an increase in the debt limit. The final columns in Tables 4 and 5 show that for all groups and instrument types.

Table 4. Sensitivity Analysis-Exchange Rate Volatility Risk Premium

\begin{tabular}{|l|cc|cc|c|}
\hline \multicolumn{1}{|c|}{ Country Group } & Risk premium & $\begin{array}{c}\text { Debt limit with 100\% } \\
\text { local currency }\end{array}$ & $\begin{array}{c}\text { Risk premium } \\
\text { range (-/+2 \%) }\end{array}$ & $\begin{array}{c}\text { Debt limit range } \\
\text { (ockeak-even' risk } \\
\text { premium }\end{array}$ \\
\hline & percent & percent of GDP & percent & percent of GDP & percent \\
\hline All countries & 2.3 & 78 & $0.1-4.1$ & $100-64$ & 5.5 \\
Emerging markets & 1.9 & 98 & $0.0-3.9$ & $138-78$ & 6.0 \\
Low income countries & 2.3 & 54 & $1.0-5.0$ & $82-42$ & 5.1 \\
\hline
\end{tabular}

1/ Relative to baseline debt level

Table 5. Sensitivity Analysis_-GDP Volatility Risk Premium

\begin{tabular}{|l|cc|cc|c|}
\hline \multicolumn{1}{|c|}{ Country Group } & Risk premium & $\begin{array}{c}\text { Debt limit with 100\% } \\
\text { local currency; 100\% } \\
\text { GDP linked }\end{array}$ & $\begin{array}{c}\text { Risk premium } \\
\text { range (-1+2 \%) }\end{array}$ & $\begin{array}{c}\text { Debt limit range } \\
\text { 'Break-even' risk } \\
\text { premium }\end{array}$ \\
\hline & percent & percent of GDP & percent & percent of GDP & percent \\
\hline All countries & 2.0 & 84 & $0.0-4.0$ & $200-54$ & 4.0 \\
Advanced economies & 1.5 & 238 & $0.2-4.2$ & $280-108$ & 3.5 \\
Emerging markets & 2.1 & 140 & $0.0-4.0$ & $200-62$ & 4.2 \\
Low income countries & 2.0 & 50 & $0.0-4.0$ & $134-34$ & 3.0 \\
\hline
\end{tabular}

1/ Relative to baseline debt level

\section{Conclusion}

32. By extending the existing set of debt limits models in the literature to incorporate additional shocks, and differentiate between country types, this framework provides a more granular framework to explore the impact that debt contract design can have on sovereign debt sustainability. This is useful for extending this literature beyond academic interest, and towards potential sovereign issuance.

33. The results of this model suggest that there is no one-size-fits-all debt structure that all countries should target. For LICs, with the lowest 'baseline' debt limit, this simple framework suggests that focus may be best directed at reducing exchange rate risk through local currency debt issuance (and building institutions that can raise the maximum sustainable primary balance). For these economies, there are well known 'original sin' constraints, so in practice it may be necessary to pursue intermediate steps, for instance by first issuing local currency inflationlinked bonds, which can reduce the risk of governments 'inflating away' their debt obligations. For EMs, once they manage to sufficiently reduce exchange rate risk, the benefits from GDP linked bonds are apparent. But AEs experience by far the largest benefit, with debt limits rising by 15 percentage points when GDP-linked bonds make up one-fifth of the debt stock.

34. The analysis also provides interesting insight on the marginal properties of GDP-linked bond issuance. When considering all economies together, there appears to be a quadratic relationship between the share of GDP-linked bonds and the debt level whereby the debt limit is maximized at 80 percent of the total stock. However, from a cost-benefit approach, sovereigns 
may choose to target lower levels, given that the 'marginal benefit' (in terms of the change in the debt limit) is declining. While not identifying the 'welfare optimal level', this framework allows these issues to be explored.

35. The results presented here are sensitive to the parameter assumptions. Perhaps the largest uncertainty surrounds the risk premium demanded by investors to hold local currency and GDPlinked bonds. In the absence of large-scale market issuance, further research in this area is important. However, this analysis does show that the benefits - in terms of higher debt limitsare robust to varying the risk premium on GDP-linked bonds across a reasonable range.

36. In addition to incorporating long maturity debt into this model, another useful extension would be to better capture the various policy frameworks in different countries. For example, 'reserve currency issuers' that typically experience 'safe haven inflows' during times of crisis arguably have a policy toolkit that can mimic many of the features of GDP linked bonds. Conversely, countries in a currency union may have significantly less scope to control nominal GDP through monetary and fiscal policy, and hence the debt-to-GDP ratio. Hence, the impact of GDP-linked bonds on their debt limit may be significantly different. 


\section{REFERENCES}

Abbas, S. A., Blattner, L., de Broeck, M., El-Gainainy, A., and Hu, M., 2014, "Sovereign Debt Composition in Advanced Economies: A Historical Perspective," IMF Working Paper 14/162 (Washington: International Monetary Fund).

Abiad, A., and Ostry, J., 2005, "Primary Surpluses and Sustainable Debt Levels in Emerging Market Countries,” IMF Policy Discussion Paper 05/6 (Washington: International Monetary Fund).

Aghion, P., Bacchetta, P., and Banerjee, A., 2001, "Currency Crises and Monetary Policy in a Credit-Constrained Economy," European Economic Review.

Allen, M., Rosenberg, C., Keller, C., Setser, B., and Roubini, N., 2002, “A Balance Sheet Approach to Financial Crisis," IMF Working Paper 02/210 (Washington: International Monetary Fund).

Amaglobeli, D., End, N., Jarmuzek, M., and Palomba, G., 2015, "From Systemic Banking Crises to Fiscal Costs: Risk Factors," IMF Working Paper 15/166 (Washington: International Monetary Fund).

Barr, D., Bush, O., and Pienkowski, A., 2014, "GDP-linked Bonds and Sovereign Default," Bank of England Working Paper 484 (United Kingdom).

Barro, R., 1995, “Optimal Debt Management,” NBER Working Paper No. 5327.

Benford, J., Best, T., and Joy, M., (with contributions from other central banks), 2016, "Sovereign GDP-linked Bonds," Bank of England Financial Stability Paper No. 39 (United Kingdom).

Blanchard, O., P. Mauro, and J. Acalin, 2016, "The Case for Growth Indexed Bonds in Advanced Economies Today," Peterson Institute for International Economics, Policy Brief No. 16-2.

Bohn, H., 1998, “The Behaviour of U.S. Public Debt and Deficits," The Quarterly Journal of Economics.

— 2005, “The Sustainability of Fiscal Policy in the United States," CESifo Working Paper No. 1446.

Borensztein, E., Chamon, M., Jeanne, O., Mauro, P., and Zettelmeyer, J., 2004, "Sovereign Debt Structure for Crisis Prevention," IMF Occasional Paper 237 (Washington: International Monetary Fund). 
Borensztein, E., and Mauro, P., 2004, “The Case for GDP-Indexed Bonds,” Economic Policy, Vol. 19, No. 38, pp. 166-216.

Bowman, J., and Naylor, P., 2016, “GDP-Linked Bonds,” Reserve Bank of Australia Bulletin, (September Quarter 2016).

Brooke, M., Mendes, R., Pienkowski, A., and Santor, E., 2013, "Sovereign Default and StateContingent Debt," Bank of England Financial Stability Paper No 27 (United Kingdom).

Chamon, M., and Mauro, P, 2005, "Pricing Growth-indexed Bonds," IMF Working Paper 14/179 (Washington: International Monetary Fund).

Cole, H., and Kehoe, H., 2000, "Self-Fulfilling Debt Crises," The Review of Economic Studies, Vol. 67, pp. 91-116.

Cruces, J., and Trebesch, C., 2013, "Sovereign Defaults: The Price of Haircuts," American Economic Journal: Macroeconomics (2014 database update).

Escolano, J., Jaramillo, L., Mulas-Granados, C., and Terrier, G., 2014, "How Much is A Lot? Historical Evidence on the Size of Fiscal Adjustments," IMF Working Paper 05/216 (Washington: International Monetary Fund).

Froot, K., Scharfstein, D., and Stein, J., 1989, “LDC Debt: Forgiveness, Indexation, and Investment Incentives," The Journal of Finance.

Ghosh, A., Kim, J., Mendoza, E., Ostry, J., and Qureshi, M., 2011, "Fiscal Fatigue, Fiscal Space and Debt Sustainability in Advanced Economies” NBER Working Paper No. 16782.

Hatchondo, J., and Martinez, L., 2002, "Long-Duration Bonds and Sovereign Defaults," Federal Reserve Bank of Richmond Working Paper 08-02

ICMA, 2017, “GDP-Linked Bonds: A New Design for Sovereign Debt Markets.” Available at: http://www.icmagroup.org/resources/Sovereign-Debt-Information/

International Monetary Fund, 2000, "Debt- and Reserve-Related Indicators of External Vulnerability." Available at (http://www.imf.org/external/np/pdr/debtres/) (Washington)

—, 2016, "Debt: Use it Wisely”, Fiscal Monitor, October (Washington).

International Monetary Fund and World Bank, 2001, "Guidelines on Public Debt Management," (Washington). 
Jeanne, O. and Zettelmeyer, J., 2002, “"Original Sin,” Balance Sheet Crises, and the Roles of International Lending", IMF Working Paper 02/234 (Washington: International Monetary Fund).

Kamstra, M., and Shiller, R., 2009, "The Case for Trills: Giving the People and their Pension Funds a Stake in the Wealth of the Nation," Cowles Foundation Discussion Paper No. 1717.

Kim, J., 2015, “Debt Maturity: Does it Matter for Fiscal Space,” IMF Working Paper 15/257 (Washington: International Monetary Fund).

Kim, J., and Ostry, J., 2017, "Boosting Fiscal Space: The Roles of GDP-linked Debt and Longer Maturities," mimeograph.

Krugman, P., 1988, “Financing vs. Forgiving a Debt Overhang,” NBER Working Paper No. 2486.

_ 1999, "Balance Sheets, The Transfer Problem, and Financial Crises," in International Finance and Financial Crises, Essays in Honor of Robert P. Flood, P. Isard and A. Rose, eds., Kluwer, Dordrecht.

Lorenzoni, G., and Werning, I., 2013, "Slow Moving Debt Crises," NBER Working Paper 19228.

Mendoza, E., and Ostry, J., 2007, "International Evidence on Fiscal Solvency: is Fiscal Policy 'Responsible'?” NBER Working Paper No. 12947.

Sachs, J., 1984. "Theoretical Issues in International Borrowing," Princeton Studies in International Finance 54

Shiller, R., 1993, "Macro Markets: Creating Institutions for Managing Society's Largest Economic Risks," Oxford University Press.

— 2003, "The New Financial Order: Risk in the 21st Century," Princeton University Press. 
AnNeX

Figure A1. ACs Growth Shock

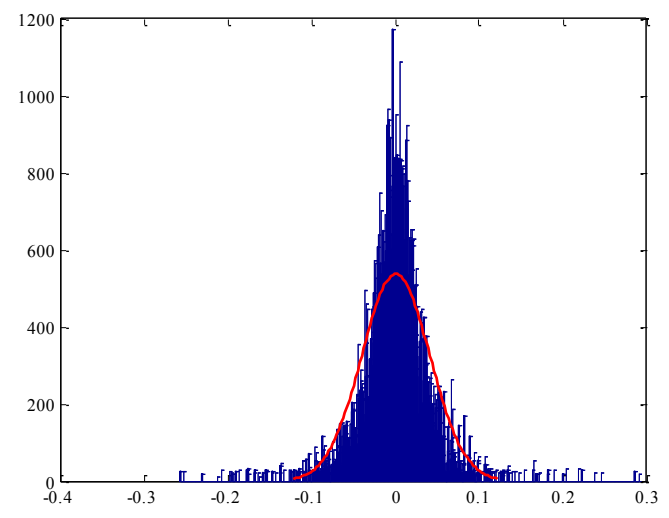

Figure A3. ACs Exchange Rate Shock

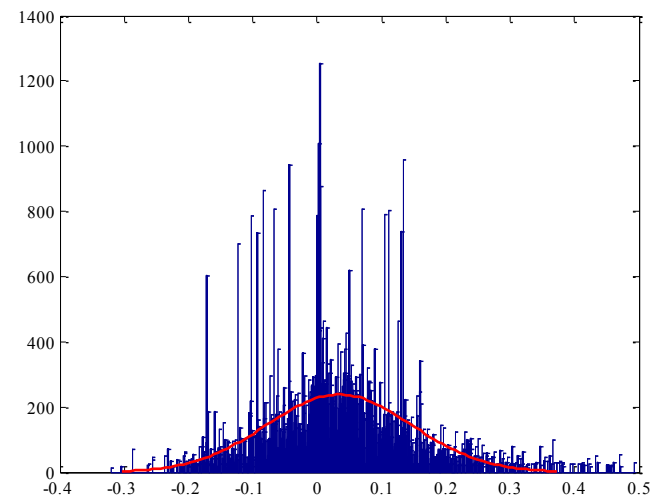

Figure A5. AEs Primary Balance Shock

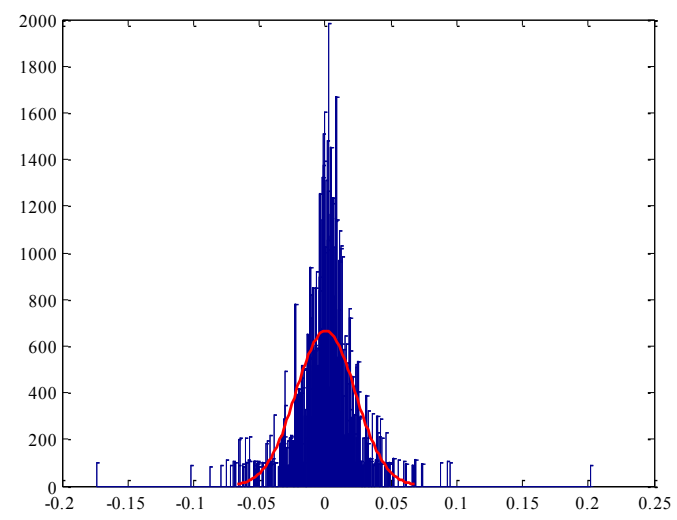

Figure A2. ACs Primary Balance Shock

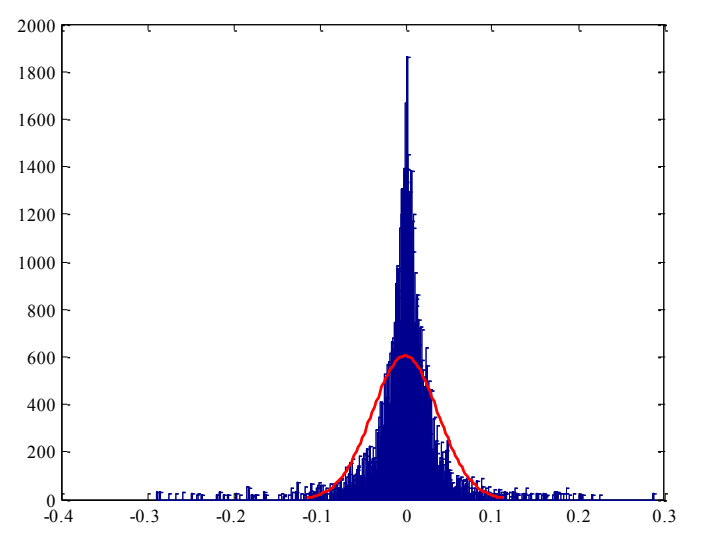

Figure A4. AEs Growth Shock

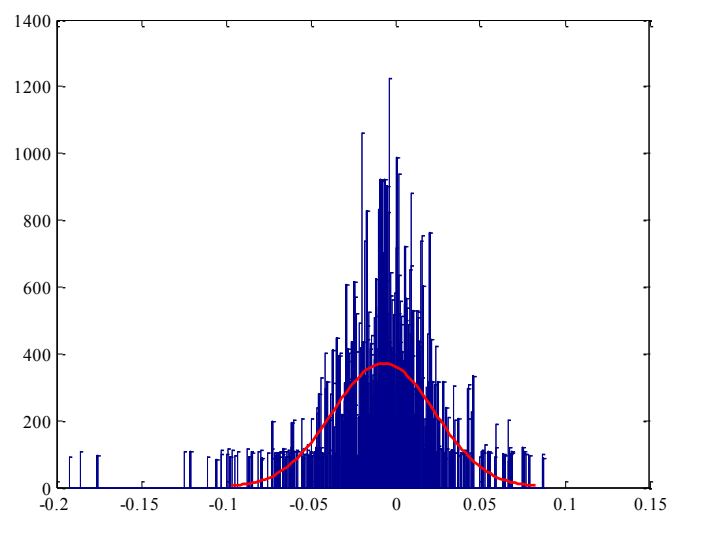

Figure A6. AEs Exchange Rate Shock

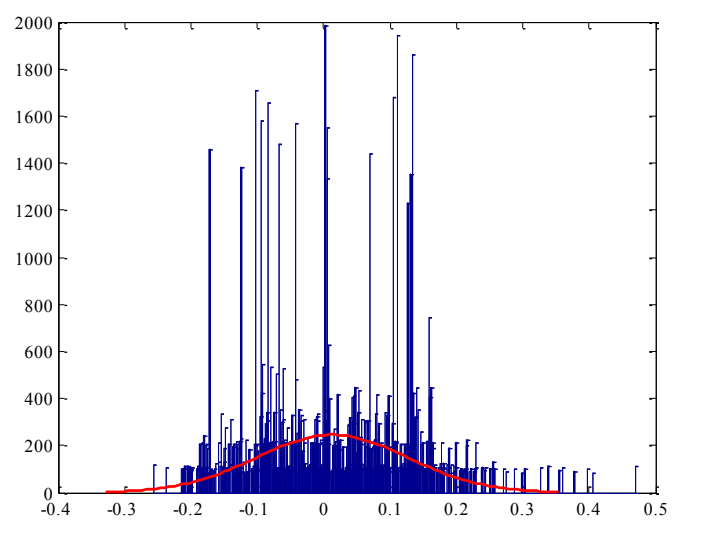


Figure A7. EMs Growth Shock

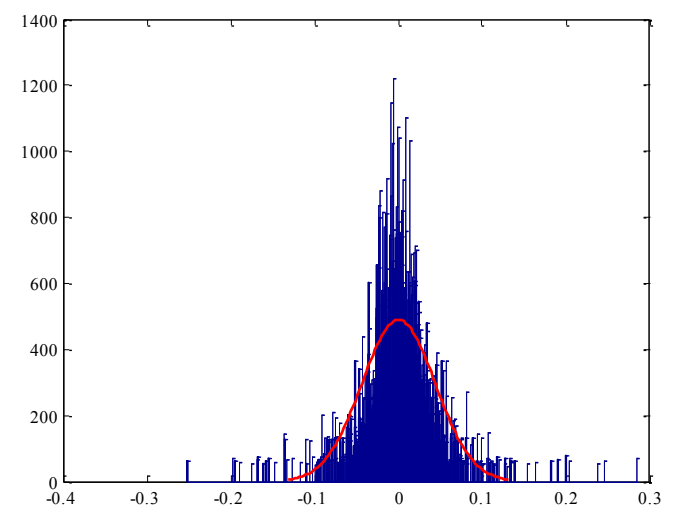

Figure A9. EMs Exchange Rate Shock

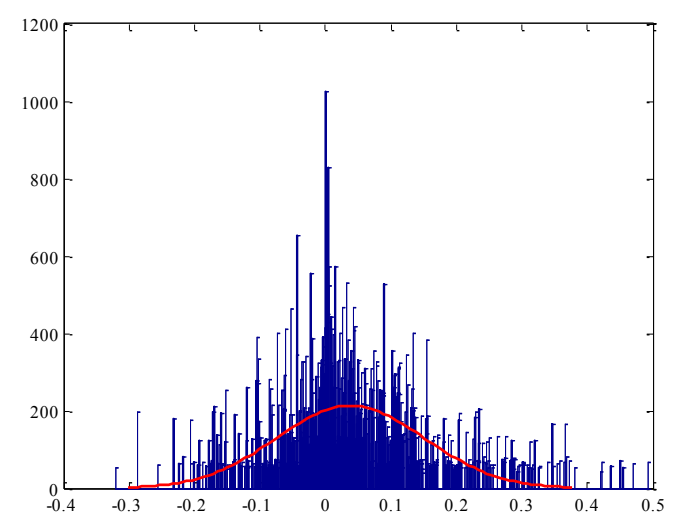

Figure A11. LICs Primary Balance Shock

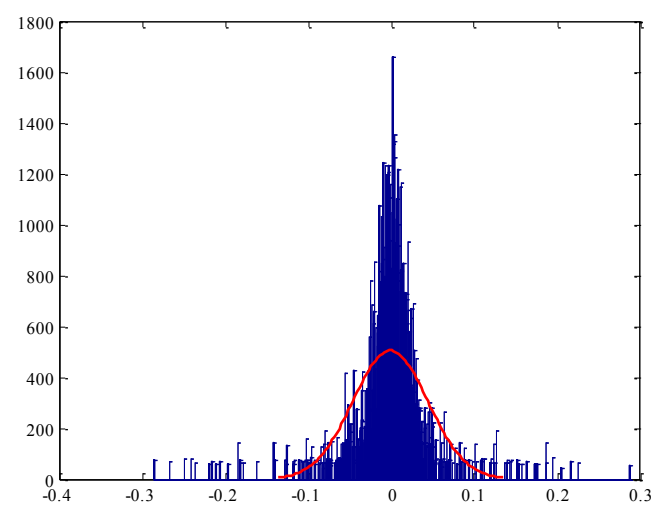

Figure A8. EMs Primary Balance Shock

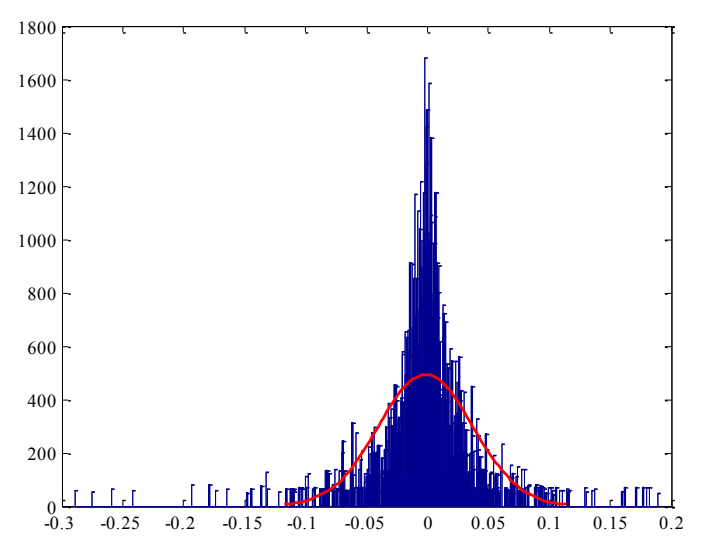

Figure A10. LICs Growth Shock

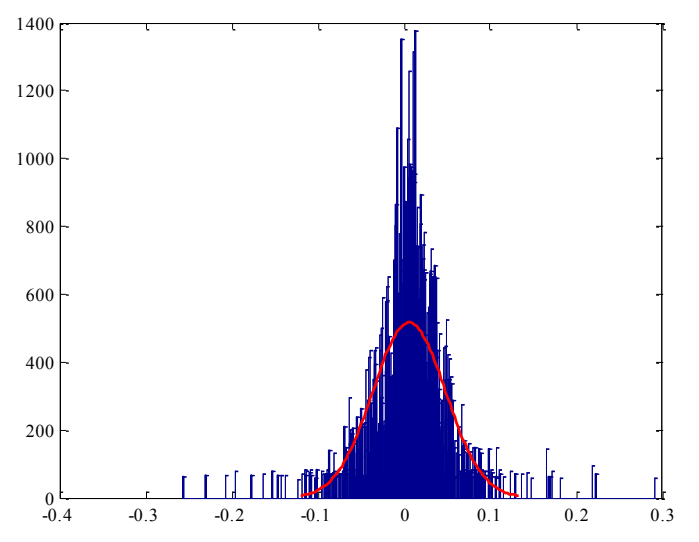

Figure A12. LICs Exchange Rate Shock

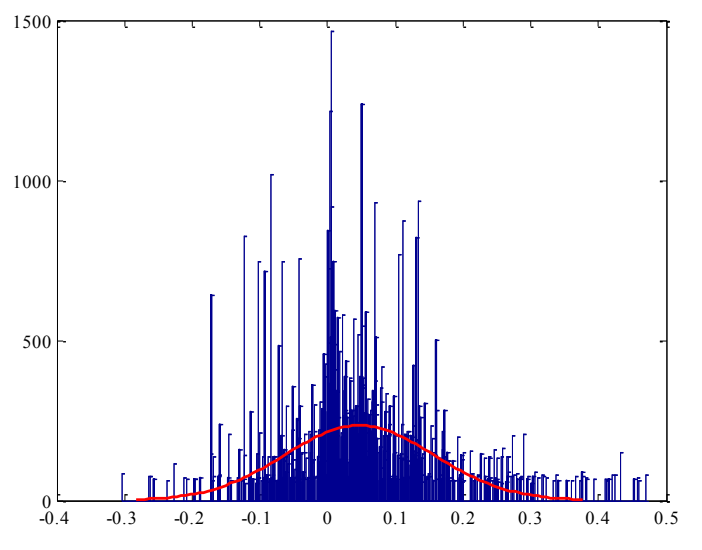


Table A1. Shock Correlations

\begin{tabular}{lccc}
\hline & $\begin{array}{l}\text { real GDP (percent change); } \\
\text { primary balance (change, } \\
\text { percent of GDP) }\end{array}$ & $\begin{array}{l}\text { real GDP (percent change); } \\
\text { real exchange rate (percent } \\
\text { change) }\end{array}$ & $\begin{array}{l}\text { primary balance (change, } \\
\text { percent of GDP); real exchange } \\
\text { rate (percent change) }\end{array}$ \\
\hline All countries & 0.12 & -0.02 & 0.01 \\
Advanced economies & 0.33 & -0.07 & -0.05 \\
Emerging markets & 0.07 & 0.17 & 0.10 \\
Low income countries & 0.05 & 0.07 & 0.10 \\
\hline
\end{tabular}

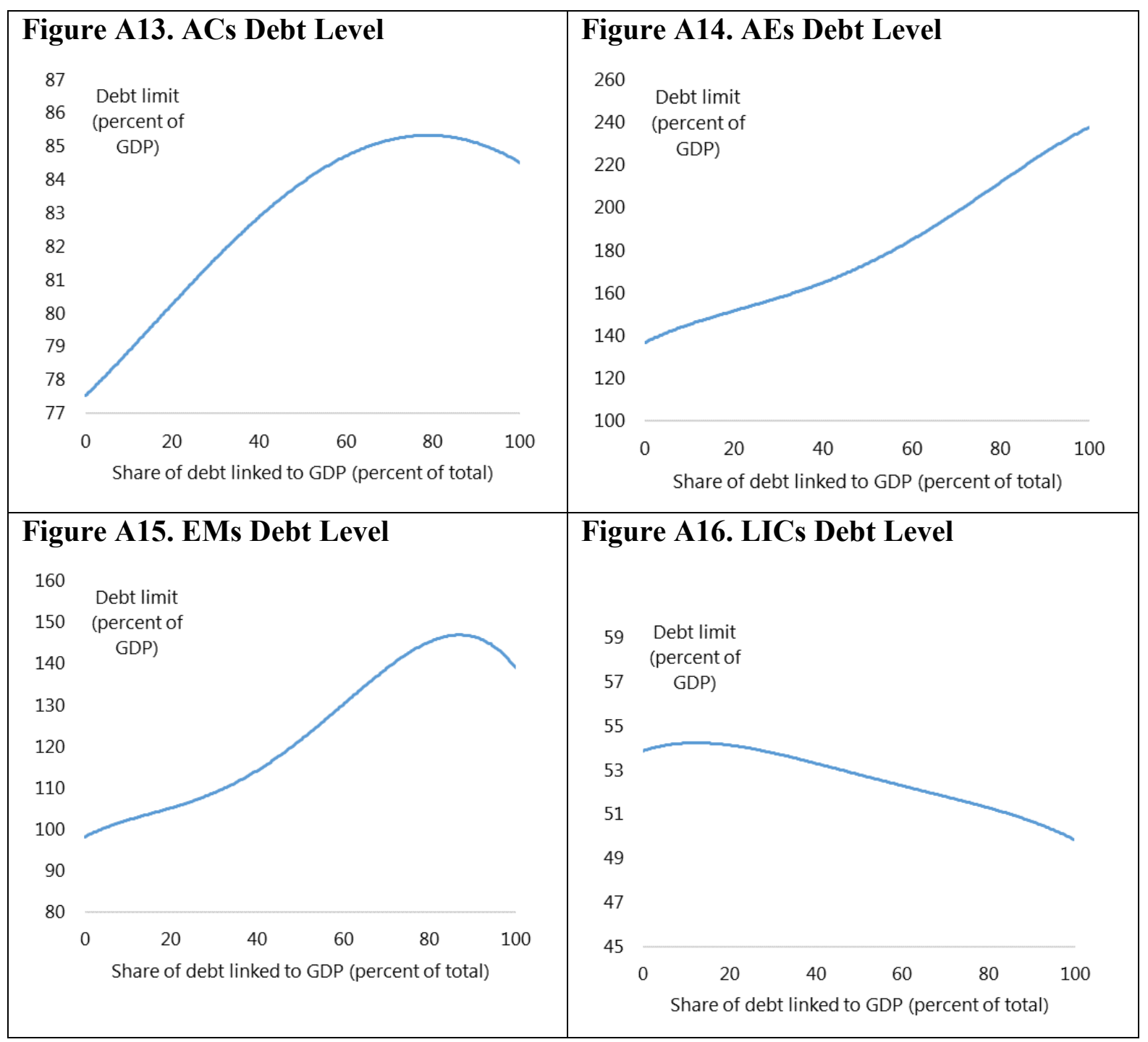

